\title{
FORMATION OF THE ETHNOCULTURAL AUTONOMY OF CHILDREN WITH ETHNOPEDAGOGICAL VALUES OF ARCTIC PEOPLES
}

\author{
FORMAÇÃO DA AUTONOMIA ETNOCULTURAL DE CRIANÇAS COM VALORES \\ ETNOPEDAGÓGICOS DE POVOS ÁRTICOS
}

\author{
FORMACIÓN DE LA AUTONOMÍA ETNOCULTURAL DE LOS NIÑOS CON \\ VALORES ETNOPEDAGÓGICOS DE LOS PUEBLOS ÁRTICOS
}

\author{
Mariia Ivanovna BAISHEVA ${ }^{1}$ \\ Irina Stepanovna ALEKSEEVA ${ }^{2}$ \\ Tatiana Alekseevna MAKAROVA ${ }^{3}$ \\ Anna Vasilievna PERMYAKOVA ${ }^{4}$ \\ Tamara Leonidovna ILINOVA ${ }^{5}$
}

\begin{abstract}
The article examines the potential of the ethnocultural environment and values related to the upbringing of the younger generation in extremely harsh conditions in the Arctic for preservation of the gene pool of ethnic groups. The research goal was to study the ethnocultural values of Arctic peoples related to the upbringing of a spiritually developed person and to form ethnocultural autonomy of preschoolers on this basis. The research basis was indigenous methodology, integrative, ethnopedagogical, activity, axiological, cultural, and learner-centered approaches. The article presents the results of a longitudinal study carried out in experimental sites over the period from 1992 to 1995 and from 2011 to 2021. The obtained scientific, theoretical, and empirical results of the study enrich the theory and practice of raising children in line with the ethnocultural values of Arctic peoples. They can be successfully applied in educational organizations of the Arctic regions.
\end{abstract}

KEYWORDS: Ethnocultural values. Preschool and school education. Arctic territory.

RESUMO: O artigo examina o potencial do ambiente etnocultural e os valores relacionados à educação da geração mais jovem nas condições extremamente adversas do Ártico para a preservação genética dos grupos étnicos. O objetivo da pesquisa era estudar os valores etnoculturais dos povos do Artico relacionados à educação de uma pessoa desenvolvida

${ }^{1}$ M.K. Ammosov North-Eastern Federal University (NEFU), Yakutsk - Russia. Associate Professor of the Pre-
School Education Department, Pedagogy Institute. Candidate of Pedagogical Sciences. ORCID:
https://orcid.org/0000-0001-6239-7531. E-mail: mariia.baisheva@yandex.ru
${ }^{2}$ M.K. Ammosov North-Eastern Federal University (NEFU), Yakutsk - Russia. Associate Professor of the
Pedagogy Department, Pedagogy Institute. Candidate of Pedagogical Sciences. ORCID: https://orcid.org/0000-
0002-4572-3363. E-mail: irina.s.alekseeva@rambler.ru
${ }^{3}$ Churapcha State Institute of Physical Culture and Sports, Churapcha - Russia. Associate Professor of the
Pedagogy and Psychology Department, Dean of the Social and Pedagogical Faculty. Candidate of Pedagogical
Sciences. ORCID: https://orcid.org/0000-0001-6015-8799. E-mail: tatiana.al.makarova@lenta.ru
${ }^{4}$ Academy of Sciences of the Republic of Sakha (YAKUTIA), Yakutsk-Russia. Junior Research Fellow. ORCID:
https://orcid.org/0000-0002-4284-3677. E-mail: anna.v.permyakova@ro.ru
${ }^{5}$ Kindergarten "Bisik", Yakutsk - Russia. Senior Nursery Teacher. ORCID: https://orcid.org/0000-0001-5652-
${ }_{352 X . \text { E-mail: tamara.ilinova@lenta.ru }}$

RPGE- Revista on line de Política e Gestão Educacional, Araraquara, v. 25, n. 3, p. 2443-2458, Sep./Dec. 2021. e-ISSN: 1519-9029 
espiritualmente e formar a autonomia etnocultural dos pré-escolares nessa base. A base da pesquisa foi a metodologia indígena, integrativa, etnopedagógica, atividade axiológica, cultural e abordagens centradas no aluno. $O$ artigo apresenta os resultados de um estudo longitudinal realizado em locais experimentais durante o periodo de 1992 a 1995 e de 2011 a 2021. Os resultados científicos, teóricos e empíricos obtidos do estudo enriquecem a teoria e a prática de criar filhos em consonância com os valores etnoculturais dos povos do Ártico. Eles podem ser aplicados com sucesso em organizações educacionais das regiões árticas.

PALAVRAS-CHAVE: Valores etnoculturais. Educação pré-escolar e escolar. Território ártico.

RESUMEN: El artículo examina el potencial del entorno etnocultural y los valores relacionados con la crianza de la generación más joven en condiciones extremadamente duras del Ártico para la preservación del acervo genético de los grupos étnicos. El objetivo de la investigación fue estudiar los valores etnoculturales de los pueblos árticos relacionados con la crianza de una persona desarrollada espiritualmente y formar la autonomía etnocultural de los niños en edad preescolar sobre esta base. La base de la investigación fue la metodología indígena, enfoques integradores, etnopedagógicos, de actividad, axiológicos, culturales y centrados en el alumno. El artículo presenta los resultados de un estudio longitudinal realizado en sitios experimentales durante el periodo de 1992 a 1995 y de 2011 a 2021. Los resultados científicos, teóricos y empíricos obtenidos del estudio enriquecen la teoría y la práctica de la crianza de los hijos en línea con los valores etnoculturales de los pueblos árticos.

PALABRAS CLAVE: Valores etnoculturales. Educación preescolar y escolar. Territorio ártico.

\section{Introduction}

In modern society that is undergoing a spiritual cataclysm, the time has come when every nation, as a bearer of spiritual values, must think about a spiritual crisis. First, people should think about themselves and take care of their spiritual life and spiritual growth. In Russia, the interaction between different cultures is tense due to national issues and mental incompatibility. Many modern Russian and international researchers believe that the solution to this problem is the focus on the individual as a dominant social value. The available scientific data indicate that preschool and primary school ages are the time when children understand social relations and social motives of people's activities, accumulate the experience of spiritual and moral actions, and learn to act according to the developed spiritual values of their people and nation.

In this regard, this research aimed to fill the existing gap in education, namely, to give theoretical and methodological basis for the formation of ethnocultural autonomy of children based on the ethnocultural values of Arctic peoples. Ethnic identity is a deep personally 
significant formation. For each person, the awareness of their belonging to a certain nation and the understanding of its features, including the specifics of the psyche, play a crucial role and have a tremendous impact on all relations between people, from interpersonal to interstate (STEFANENKO, 2009). Therefore, it is necessary to study ethnic factors related to personality formation and development. Activation of deep personal processes dealing with the specifics of the ethnocultural values of Arctic peoples, inclusion of these processes into modern life are currently one of the vital measures for raising a spiritually developed personality.

The research goal was to study the ethnocultural values of Arctic peoples related to the upbringing of a spiritually self-sufficient person and to form ethnocultural autonomy in preschool children in line with ethnopedagogical values. Working on the study, we put forward a hypothesis that to create pedagogical conditions for the formation of ethnocultural autonomy of preschool children in line with the ethnocultural values of Arctic peoples, it is necessary to devise educational programs for institutions of different levels.

The theoretical and practical significance of the study includes the following. We determined the essence and components of the category ethnocultural autonomy as a value quality of a person and revealed the essence of ethnopedagogical laws of raising a self-sufficient person based on ethnopedagogical "Aiyy" of Arctic peoples. The materials developed and research conclusions drawn qualitatively enrich the spiritual and moral education of children in educational organizations, teach children a tolerant attitude to the cultures of various ethnic groups, increase their motivation and desire to learn, as well as preserve and develop their national culture. The research materials can be used for training educators, creating ethnocultural and multicultural content of various academic courses, designing educational programs in modern nursery schools and institutions of different levels, and to describe the components of ethnocultural autonomy as a spiritual and moral quality of a person. In addition, the research findings can be applied to substantiate the fundamental syuo ideas and laws of the tuskul subprograms of forming the creative personality of the Aiyy person among the peoples of the North. These are the main ideas and means to activate the mechanisms for the formation of the ethnocultural autonomy of children in educational organizations.

\section{Literature review}

The issues of ethnic and national identity, the role of national values and traditions when choosing the ways to reform and develop Russia have recently been in the focus of attention of Russian and international cultural studies scholars, philosophers, psychologists, sociologists, 
and political scientists (BERKOVICH, 2014; BLEDAI; KUPINA, 2017; DUTKIN, 2018; GABYSHEVA, 2015; KAMENOV, 2020; KING; DEDYK, 2015; KURBANOV, 2012; OCAMPO; BERNAL; KNIGHT 1993; PARIS, 2001; PIAGET; WEIL, 1951; STARES, 2014; STEFANENKO, 2009; WANG; LEHTOMAKI, 2021). These authors consider ethnocultural identity a significant direction of national security.

According to A. S. Berberyan and E. S. Berberyan (2017), the content characteristics of a person's understanding of their ethnocultural identity manifest themselves in some constructs, including the perception of oneself in the context of ethical norms and values and the dominant type of self-interpretation.

To examine the research concept and to determine its scientific and theoretical foundations, we studied the works of the researchers, who consider the development of the ethnocultural identity of a person a universal value. This person is aware of their identity and connection with their native people, accepts the cultural values of other peoples, and is tolerant in a multicultural society. These researchers (BAISHEVA; SIDOROVA, 2020; BERKOVICH, 2014; BLEDAI; KUPINA, 2017; KURBANOV, 2012; NEPOMNJASHHAJA， 2018; PANKIN, 2009; POSHTAREVA, 2009; ROBBEK, 2007; RYNDINA, 2018; SEMENOVA, 2014) demonstrate how all these essential spiritual qualities of a person form an autonomous creative personality.

An important element of this study was the concept of Jean Piaget. According to it, identification is based on parents' nationality, place of residence, and knowledge of one's native language. All this serves as the basis for the formation of a complex ethnic identity, when the child comprehends the unique nature of the history, culture, and life of their ethnic group. As we can see, the child's ethnic identity forms when they master the culture of their native people, become aware of it, and accept it, i.e., during inculturation.

Khairova (2019) shows that in diverse information flow that surrounds children, the language and national dress have the greatest impact on the formation of the image of their national culture.

Piaget and Weil (1951) claim that at the age of 10-11 years, children form a comprehensive ethnic identity and comprehend the uniqueness of the history, culture, life of their native ethnic group. An analysis of the works of international authors shows that the formation of ethnic identity in children occurs when they become part of the culture of their native people, through their awareness and acceptance, i.e., inculturation.

Bledai and Kupina (2017) claim that when learners immerse in the cultural environment, they master the culture and create it at the same time. Within ethnocultural education, life 
activities familiarize the child with the national culture and thereby satisfy their national and cultural needs. We agree with this opinion. However, there has been no comprehensive research into these issues. Studying the ethnocultural environment in which the child of the Arctic grows up is an important factor in the development of their ethnocultural autonomy.

According to Gabysheva (2015), to form civil and ethnocultural identity, it is necessary to develop a strategy of ethnocultural education in a multicultural space, which can be built as a model of the ethnic culture itself. It is no secret that the representatives of ethnic minorities experience fear and discrimination regarding the linguistic and other competencies when they communicate with the representatives of the multicultural world.

Students in other countries also face language discrimination and difficulties entering prestigious schools. According to Wang and Lehtomäki (2021), when studying the sociocultural attachment of national minorities in China, researchers estimated that, firstly, the socioeconomic status of the ethnic minority family plays the leading role when choosing a school. Secondly, the school environment directly depends on learning achievements and professional expectations of students. Thirdly, the cultural attachment of the minority to their native language has diminished significantly among those who attend Chinese-only schools, but there has been no significant difference among students in schools with bilingual education.

One of the factors in the development of autonomy in Arctic children is knowledge of their native language. Thanks to the language, our traditions continue to live, the language arouses interest in understanding the world and increases respect for our past, and it is an element that unites people. Language forms the personality of its speaker (WANG; LEHTOMÄKI, 2021).

According to Dutkin (2018), indigenous peoples experience a kind of cultural and psychological trauma. This trauma is due to such a sociopsychological phenomenon as European ethnocentrism. A sense of national identity is suppressed among indigenous people. All this undermines the psychological stability of indigenous people and increases their psychogenic vulnerability, which manifests itself in the development of suicidal behavior. The author believes that multiculturalism means mutual adaptation of different groups of people, the creation of more favorable conditions for national minorities, which will decrease the suicide rate of indigenous peoples globally. Obviously, suicide and stress rates, even among young schoolchildren, are associated with the psychopathological factors of living in the extreme conditions of the Far North, as well as other unfavorable factors of the micro- and macrosocial environment of ethnic minority habitats. Loginov, Ignatyeva, and Balashenko (2018) assume that the regions of the Russian North differ significantly in terms of 
socioeconomic development. In this regard, researchers note the negative impact of industrial development in traditional habitats of ethnic minorities and highlight the difficulties of social adaptation.

According to Berkovich (2014), to prevent the crisis of the Russian ethnic communities, the leading strategy should be the development of autonomy. The proposed classification is an interconnected sequence, in which the basic, generic concept is self-organization. Selforganization is a universal general predisposition of society towards autonomy, selfdetermination, self-regulation, and, consequently, towards self-reproduction and selfidentification. Self-reproduction and self-determination are the basis of the autonomy of an ethnos as a nonlinear and irregular formation possessing its inherent special systemic connections (BERKOVICH, 2014). Individuals form their worldview by assimilating certain cultural values (YUROCHKIN, 2014). Under such difficult socioeconomic, natural, and climatic conditions, only boosting the morale, promoting love for their native places, and developing ethnocultural autonomy as a persistent value quality of the individual can ensure the spiritual and psychological safety of children.

\section{Materials and methods}

The longitudinal study was carried out in the Kustuk Nursery School No. 26, Yakutsk Pre-School Educational Organization No. 3 "Cheburashka" of Zhatay city district, the Bisik Early Childhood Development Center in the village of Antonovka in Nyurba district, Secondary School No. 2 of Yakutsk city, a secondary school in the village of Tanda in Ust-Aldan region, and a secondary school in the village of Eyik in the Olenek region. To explore the research problem, the authors applied the following methodological approaches:

- Indigenous methodology aims to enrich science with the worldview and experience of indigenous peoples possessing a rich cultural and intellectual heritage;

- The integrative approach examines ethnocultural autonomy as an integral phenomenon, the internal unity that is consistent, structured, and stable;

- The ethnopedagogical approach reveals the significance of the spiritual values preserved in the traditional culture of the people, not as local and static phenomena, but as dynamic and integrated value qualities; 
- The activity approach explores the development of ethnocultural autonomy as a socially valuable and personally significant activity of the subject, motivating the individual to cultivation and spiritualization of students' relationships with others;

- The learner-centered approach provides support for ethnocultural autonomy as a universal value of the individual and integration of national values into personal values;

- The axiological approach focuses on new conceptual formations, which act as the main constructing units of the person's consciousness;

- The cultural studies approach enriches the environment with ethnocultural values and encourages filling it with the values of Arctic peoples, as well as national and universal culture.

Table 1 presents the principles we applied in this study.

Table 1 - Research principles

\begin{tabular}{|c|c|}
\hline Principle & \\
\hline $\begin{array}{l}\text { Spirituality and } \\
\text { creativity }\end{array}$ & $\begin{array}{l}\text { Developing creativity and the ability to differentiate between good and evil; } \\
\text { activating and building values underlying the mentality of a person; and forming } \\
\text { an internal system of moral behavior regulators of behavior. }\end{array}$ \\
\hline $\begin{array}{l}\text { Focus on the } \\
\text { ideal }\end{array}$ & $\begin{array}{l}\text { Teaching with kindness and love, upbringing based on freedom, beauty, and } \\
\text { creativity, and supporting all these features in the child; creating favorable } \\
\text { conditions for the child's mastery of the values of human life and acquisition of } \\
\text { personal meanings in the attitude towards the world, people, and oneself; } \\
\text { supporting the child's striving for the national ideal of a creative personality as a } \\
\text { source of harmony between a person and life. }\end{array}$ \\
\hline $\begin{array}{l}\text { Mentality } \\
\text { formation and } \\
\text { transformation }\end{array}$ & $\begin{array}{l}\text { Appreciation of the child as a subject of culture, and spiritual activity that ensures } \\
\text { their mastery of cultural values, meanings, as well as the foundations of their } \\
\text { personal life stance and lifestyle; creating the conditions for the development of a } \\
\text { free, humane, spiritual personality, ready to live in modern ethnocultural and } \\
\text { sociocultural reality, and open to the world culture. }\end{array}$ \\
\hline Agency & \\
\hline $\begin{array}{l}\text { Acceptance of } \\
\text { the child as they } \\
\text { are }\end{array}$ & $\begin{array}{l}\text { gnition and acceptance of the child as an actor of life, culture, and society, } \\
\text { is capable of cultural self-development in accordance with universal human } \\
\text { al standards here and now. }\end{array}$ \\
\hline
\end{tabular}

Source: Prepared by the authors

In the conditions of a spiritual crisis, surrounding the child with new meanings, integrating values into behavior, and cultivating their ontological spiritual and moral potential are the measures that will prevent the spiritual destabilization of society. Conducting the experiment, we used the following research methods: 
- Structural and comparative analysis of the existing models of ethnocultural education of children based on the values of the peoples living in the Arctic zone, including other countries;

- The inductive and deductive method to explore the practices promoting ethnocultural autonomy through ethnopedagogical traditions and values of Arctic peoples;

- Identifying and resolving contradictions when studying international and Russian experience related to developing ethnocultural autonomy of students;

- Empirical methods for studying the social environment of children by using special questionnaires.

Focus on the interests of the indigenous minorities of the North in the Republic of Sakha (Yakutia) and their historical and spiritual heritage are among the main priorities of the state policy of the Republic. Yakutia is home to 39,936 people, including 21,008 Evenks, 15,071 Evens, 1,281 Yukagirs, 1,906 Dolgans, and 670 Chukchi. The rights of indigenous minorities in the republic are protected by the Concept for Sustainable Development of the Arctic Uluses and Places of Compact Accommodation of Indigenous Minorities in the North of the Republic of Sakha (Yakutia) until 2020. Its goals and objectives reflect the main vectors of the Strategy of the State National Policy of the Russian Federation for the period until 2025 and the Concept of Sustainable Development of Indigenous Peoples of the North, Siberia, and the Far East of the Russian Federation.

Ethnocultural autonomy is formed with educational programs. For this purpose, one should carefully analyze methods and forms of working with children. The reproduction of ethnocultural values of Arctic peoples helps prevent spiritual destruction. These values imply the principles of biologism, psychologism, sociologism, humanization, and worthiness.

\section{Results}

The research papers we examined focus on the formation of ethnocultural identity in children. However, they do not define the essence of the scientific category ethnocultural autonomy. Ethnocultural autonomy is not only the awareness of one's ethnocultural identity. A child should go beyond the awareness of the culture and life of their native people, they should be open to, be aware of, and accept the cultures of other peoples. Only in this case they can comprehend and recognize themselves as a self-sufficient ethnocultural subject of multinational 
Russia and the multicultural world as a whole. Thus, we defined ethnocultural autonomy as a universal value of a person who is aware of their identity and the relationship with their native people, who accepts the values of the cultures of other peoples, and is tolerant in a multicultural society. Combined, all these essential spiritual qualities of a person form an autonomous creative person.

Figure 1 - Formation of ethnocultural autonomy of children based on the ethnopedagogical values of Arctic peoples

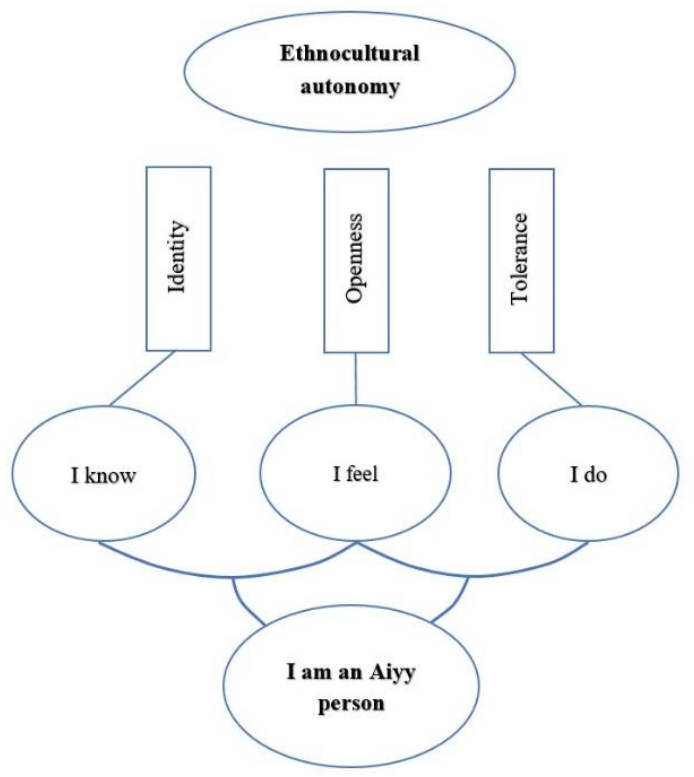

Source: Prepared by the authors

Objective and subjective ethnopedagogical factors play crucial role in the formation of ethnocultural autonomy. Objective ethnopedagogical factors include the influence of ethnic traditions and customs, whereas subjective factors refer to ethnic consciousness and thinking, as well as ethnic characteristics of the perception of the world and nature.

To devise educational programs in the preschool and primary school groups where we conducted the experiment, we identified how ready older preschoolers and young schoolchildren were to perceive and understand ethnic ideas that act as a cognitive subsystem of mentality. We substantiated the spiritual and moral foundations of Arctic peoples, which include tribal and sociocultural solidarity, openness, tolerance towards others, hospitality, hard work, honesty, physical strength, endurance, and comprehensive awareness of the natural world (intuitive, sensory-eidetic, and logical).

Having conducted the longitudinal study, we obtained information about the ethnopsychological characteristics of preschool children. We used this data to devise the educational content and methods of working with children that provided missing theoretical 
and practical knowledge about children of the ethnic minority groups in kindergartens (Table 2).

Table 2 - Revealed ethnopsychological specifics of preschoolers raised in traditional culture

\begin{tabular}{|l|}
\hline \multicolumn{1}{|c|}{ Obedience and diligence } \\
\hline Assertiveness and perseverance in achieving goals in any type of activity \\
\hline $\begin{array}{l}\text { Readiness for interaction and sincere communication, which manifests itself not in words, but goes } \\
\text { from the heart }\end{array}$ \\
\hline $\begin{array}{l}\text { Readiness for team work, but the child may sometimes insist on their opinion, which may occasionally } \\
\text { be interpreted as manifestations of rudeness }\end{array}$ \\
\hline Developed ability to perceive the beauty of nature and the surrounding reality \\
\hline Observation skills, sensory sensitivity, and a special flair for sounds and colors \\
\hline $\begin{array}{l}\text { Curiosity, flexibility, ingenuity, imaginativeness, sound judgment, perseverance, and resourcefulness } \\
\text { when solving problems }\end{array}$ \\
\hline
\end{tabular}

Source: Prepared by the authors

During the experiment, we used codes, i.e., syuo ideas of ethnopedagogical laws of Sakha, Evens, and Evenks. These nine tuskul subprograms are key elements in the upbringing of a creative Aiyy person. All Arctic peoples incorporate such syuo ideas in the laws of the upbringing of a creative (perfect) person (Table 3 ).

Each tuskul subprogram of the nine Aiyys performs a certain function and provides a unique reflection of the values of human life. Together, they recreate the spiritual, moral, ecological, ethical, and aesthetic ideas of the people. According to the views of the people, a perfect human is a deeply harmonious and spiritual person, the Aiyy person (BAISHEVA, 2015).

Table 3 - Syuo ideas and tuskul subprograms of ethnopedagogical laws for raising the creative Aiyy person

\begin{tabular}{|l|l|l|}
\hline No & $\begin{array}{l}\text { Name of the tuskul } \\
\text { subprogram }\end{array}$ & \multicolumn{1}{|c|}{ Educational essence of the tuskul subprogram } \\
\hline 1. & Aiyykhyt & $\begin{array}{l}\text { Ensuring the spiritual and physical protection of the child and their } \\
\text { awareness of their own safety, bond with parents, family, hearth, and } \\
\text { home. }\end{array}$ \\
\hline 2 & Ieyiekhsit & $\begin{array}{l}\text { Instilling a careful and sensible attitude to the fragile world of northern } \\
\text { nature; human is not a master, but a child of nature. }\end{array}$ \\
\hline 3 & Diesyogyoy Aiyy & $\begin{array}{l}\text { Teaching hard work, physical strength and endurance in harmony with } \\
\text { spirit and nature. Harmony of spirit and physical strength is a } \\
\text { prerequisite of creativity. }\end{array}$ \\
\hline 4 & Hotoy Aiyy & $\begin{array}{l}\text { Teaching unity, solidarity, and consolidation as an organizing } \\
\text { principle, orderliness, and sustainable development of life. }\end{array}$ \\
\hline 5 & Uluu Suorun Aiyy & $\begin{array}{l}\text { Teaching three vital labor skills: blacksmithing, the art of healing, and } \\
\text { storytelling. }\end{array}$ \\
\hline
\end{tabular}




\begin{tabular}{|l|l|l|}
\hline 6 & Sung Dyasyn Aiyy & $\begin{array}{l}\text { Teaching children to be peaceful, decent, honest, reasonable, kind, } \\
\text { high-minded, selfless, and generous even in the most difficult life } \\
\text { situations. }\end{array}$ \\
\hline 7 & $\begin{array}{l}\text { Dylga Toyon Aiyy, } \\
\text { Tankha, Bilge }\end{array}$ & $\begin{array}{l}\text { Developing various ways of comprehending the multidimensional } \\
\text { world and its laws by the multidimensional Aiyy person (intuitive, } \\
\text { logical, and sensory-eidetic abilities of children). Ensuring that } \\
\text { children are open to nature and free. }\end{array}$ \\
\hline 8 & $\begin{array}{l}\text { Odun Khaan and } \\
\text { Chyngys Khaan } \\
\text { Aiyy }\end{array}$ & $\begin{array}{l}\text { Ensuring understanding that the Aiyy person is the master of their life } \\
\text { course; teaching children to follow Aiyy laws, then a person "will get } \\
\text { wealthier for three hundred centuries, prosperous for four hundred } \\
\text { centuries, and for nine centuries they will be happy, and it will never } \\
\text { be over". }\end{array}$ \\
\hline 9 & $\begin{array}{l}\text { Yuryung Aiyy } \\
\text { Toyon }\end{array}$ & $\begin{array}{l}\text { Harmonization of human relations with the laws of the Kuyaar } \\
\text { Universe; development of the highest quality state of human - life } \\
\text { creation. }\end{array}$ \\
\hline
\end{tabular}

Source: Prepared by the authors

These values of circumpolar peoples act as the basis for the moral imperatives of children's ethnocultural autonomy. During the experiment, we devised the programs for the formation of ethnocultural autonomy in preschoolers and primary school students, a program for the spiritual safety of children in preschool education, as well as long-term programs (five years) to eliminate stress factors in students of the risk group.

The programs define the directions, blocks, and themes of children's educational activities aimed at the formation of their ethnocultural identity, openness, and tolerance, as well as the provision of social and psychological support to children and families. Experimental work on spiritual safety included three directions:

1. The development of the child's spiritual identity with their family, clan, people, and homeland and the formation of the qualities of spiritual safety of a person;

2. The formation of dignity and spiritual responsibility in a child as the basis of their spiritual actions and behavior with such sections as "My spiritual ideal" and "My path of ascent to the spiritual ideal";

3. Formation of a tolerant personality as the basis of creativity in a multicultural world.

Working with children, we applied the principles of openness, humanization, a learnercentered approach, and tolerance.

The developed long-term programs were implemented by the joint efforts of all schoolteachers and the village community. Such collaboration with social partners contributed to efficient reduction in stress factors experienced by Arctic children, ensured social, spiritual, and psychological safety of the learners, and promoted the development of worthiness and autonomy as the essential qualities of the child's personality. 


\section{Discussion}

In our study, we defined ethnocultural autonomy as the worthiness of a person who is aware of the identity and bond with their native people, who accepts the values and culture of other peoples, and is tolerant towards other nations. It is argued that a child reproduces values when they discover, understand, and become involved in the life of a creative person, which is connected to the life of their parents - family, clan, nation, humanity, village, city, region or country, and the world. Only then a person can consider themselves an autonomous ethnocultural subject of a multinational Russia and the multicultural world as a whole.

We believe that ensuring ethnocultural autonomy means ensuring the child's autonomy in communication not only in their ethnocultural environment, but also in the environment of other ethnic groups, as well as the global environment. From their birth, a child should not feel discriminated, isolated from communication with others. From an early age, they must understand that there are no big or small cultures. Teachers should educate children as a subject of culture of the big and small Motherland here and now. Thus, the formation of the foundations of ethnocultural autonomy in students from preschool age will not only decrease stress factors, but will also contribute to comprehensive spiritual and mental safety, as well as the harmonious development of the personality.

\section{Conclusion}

The relevance of our research stems from the fact that we substantiated the spiritual and moral foundations of the peoples of the North and developed conceptual foundations and a structural and functional model for the formation of ethnocultural autonomy of students. In addition to this, we defined the directions and the content of teaching and upbringing of a child of traditional culture and their practical implementation in the educational process of kindergartens and schools.

The longitudinal study was conducted on experimental sites from 1992 to 1995 and from 2011 to 2021 . We substantiated the theoretical and methodological prerequisites and conceptual foundations for the formation of ethnocultural autonomy of children, developed educational programs for preschoolers and primary school students, as well as long-term programs (five years) to reduce stress factors in school students of the risk group. We determined the syuo ideas and tuskul subprograms in line with the ethnopedagogical laws of Sakha, Evens, and Evenks. They were the basis for educational programs and a prerequisite for the upbringing of a creative personality among the peoples of the Arctic. 
The research findings provided us with substantive information about the ethnopsychological characteristics of children raised in traditional culture. We used these conclusions to develop ethnopedagogical techniques of working with students. In addition to this, we published monographs, educational, and methodological kits for students on the problems of ethnocultural education and spiritual safety.

The obtained scientific, theoretical, and empirical results of the study enrich the theory and practice of raising children according to the ethno-pedagogical values of Arctic peoples and can be successfully applied in educational organizations of the Arctic regions.

\section{REFERENCES}

BAISHEVA, M. I. Formation of a creative person in the ethnocultural traditions of the Sakha people. Yakutsk: NEFU Publishing House, 2015. In Russian.

BAISHEVA, M. I.; SIDOROVA, L. S. Family in the 21st century: Problems and prospects: A collection of articles based on the materials of the 3rd all-Russian scientific and practical conference of undergraduates, teachers, public figures, and practitioners. Barnaul: OOO "Pyat Plus", 2020. p. 132-136. In Russian.

BERBERYAN, A. S.; BERBERYAN, E. S. Etnopsihologicheskie aspekty smyslozhiznennyh i cennostnyh orientacij studencheskoj molodezhi, Voprosy psihologii [Ethnopsychological aspects of the meaning-of-life and value orientations of students]. Voprosy Psikhologii [The Issues Relevant to Psychology], Moscow, v. 1, p. 103-115, 2017.

BERKOVICH, N. A. Rossijskij ètnosocium: Strategija samodostatočnosti i konsolidacii [Russian ethnosocium: Strategy of self-sufficiency and consolidation]. Ètnosocium i mežnacional'naja kul'tura [Ėtnosocium and Interethnic Culture], Moscow, v. 4, n. 70, p. 914, 2014. Available: http://etnosocium.ru/sites/default/files/etnosocium_mag/201404mag.01.pdf. Access: 7 Dec. 2021.

BLEDAI, V. V.; KUPINA, N. V. [Formation of ethnocultural self-identification of students in the educational space of educational institutions]. Obrazovanie i Vospitanie [Education and Upbringing], v. 3, n. 13, p. 3-5, 2017.

DUTKIN, M. P. Etnokul'tural'nye faktory suitsidal'nogo povedeniia u korennykh narodov [Ethnocultural factors of suicidal behavior in indigenous peoples]. Vestnik SeveroVostochnogo Federal'nogo Universiteta Imeni M.K. Ammosova [Bulletin of the M.K. Ammosov North-Eastern Federal University], Yakutsk, v. 4, n. 13, p. 64-75, 2018.

GABYSHEVA, F. V. [The formation of civic and ethnocultural identity requires the development of a strategy of ethnocultural education in a multicultural space, which may be built as a model of ethnoculture itself]. In: VINOKUROVA, U. A. (Ed.). Ètnokul'turnoe obrazovanie v Dal'nevostočnom federal'nom okruge Rossijskoj Federacii [Ethnocultural Education in the Far Eastern Federal District of the Russian Federation]. A collective monograph. Yakutsk: Yakutia Media Holding, 2015. 
KAMENOV, L. Development and current models of interaction "educational institutions family" as measures to take over reflective factors for discrimination in education. Strategies for Policy in Science and Education, Sofia, v. 28, n. 1, p. 78-93, 2020. Available: https://azbuki.bg/wp-content/uploads/2020/03/mostra_tialo.pdf. Access: 7 Dec. 2021.

KHAIROVA, S. I. Manifestations of ethnic identity children of preschool and primary school age. In: SOCIAL AND CULTURAL TRANSFORMATIONS IN THE CONTEXT OF MODERN GLOBALISM (SCTCGM), 2018, Groznyi. Proceedings [...]. London: The European Proceedings of Social \& Behavioural Sciences, 2019. p. 2226-2238. DOI: https://doi.org/10.15405/epsbs.2019.03.02.258

KING, A. D.; DEDYK, V. R. The relationship between language and culture: Documentation of disappearing dialects of the Koryak language. In: VINOKUROVA, U. A. (Ed.). Ètnokul'turnoe obrazovanie v Dal'nevostočnom federal'nom okruge Rossijskoj Federacii [Ethnocultural Education in the Far Eastern Federal District of the Russian Federation]. A collective monograph. Yakutsk: Yakutia Media Holding, 2015.

KURBANOV, N. I. Ethnocultural identity in the modern sociocultural situation. Author's Abstract of the Dissertation of the Candidate of Cultural Studies. Moscow, 2012.

LOGINOV, V. G.; IGNATYEVA, M. N.; BALASHENKO, V. V. Ètnosocioèkosistemnyj podhod k ocenke žiznedejatel'nosti korennyh maločislennyh narodov Severa [Ethnic social and ecosystem approach to the evaluation of the lifehoods of small indigenous peoples of the North]. Ėkonomika Regiona [Economy of Regions], Ekaterinburg, v. 14, n. 3, p. 896-913, 2018. DOI: https://doi.org/10.17059/2018-3-15

NEPOMNJASHHAJA, N. I. Psychodiagnostics of personality: Theory and practice. Norderstedt: Book on Demand, 2018.

OCAMPO, K. A.; BERNAL, M. E.; KNIGHT, G. P. Gender, race, and ethnicity: The sequencing of social constancies. In: BERNAL, M. E.; KNIGHT G. P. (eds.). Ethnic Identity: Formation and Transmission among Hispanics and Other Minorities. Albany: State University of New York Press, 1993. p. 11-30.

PANKIN, A. B. Ethnocultural Connotation of Education. 2009. Monograph - Kalmyk State University, Elista, 2009. In Russian.

PARIS, R. Human Security: Paradigm Shift or Hot Air? International Security, Massachusetts, v. 26, n. 2, p. 87-102, 2001. Available: https://www.jstor.org/stable/3092123. Access: 7 Dec. 2021.

PIAGET, J.; WEIL, A.-M. The development in children of the idea of the homeland and of relations with other countries. International Social Science Bulletin, v. 3, p. 561-578, 1951.

POSHTAREVA, T. V. Formation of ethnocultural competence of students in a multiethnic educational environment. 2009. Dissertation (Doctorate in Pedagogical Sciences) - Vladikavkaz, 2009. In Russian. 
ROBBEK, V. A. Scientific basis of creation of the education system of nomad peoples of the North [Naučnye osnovy sozdanija sistemy obrazovanija kočevyh narodov Severa]. Novosibirsk: Nauka, 2007. 60 p.

RYNDINA, O. M. Kody tradicionnoj kul'tury i ètničeskaja identičnost' v sovremennosti [Codes of traditional culture and ethnic identity in modern times]. Kul'tura v Evrazijskom Prostranstve: Tradicii i Novacii [Culture in the Eurasian Space: Traditions and Innovations], Moscow, v. 1, n. 2, p. 40-44, 2018. DOI: https://doi.org/10.32340/2541-772X2018-1-40-44

SEMENOVA, S. S. Mežkul'turnyj dialog kak sposob formirovanija graždanskoj, regional'noj i ètnokul'turnoj identičnostej u škol'nikov [Cross-cultural dialogue as the way of formation by civil, regional and ethnocultural identity at school students]. Sibirskij Pedagogičeskij Žurnal [Siberian Pedagogical Journal], Novosibirsk, n. 1, p. 52-55, 2014. Available: http://en.spjournal.ru/system/files/articles/pdf/semenova.pdf. Access: 7 Dec.2021.

STARES, P. "New" and "non-traditional" security challenges. In: VAN GINKEL, H.; THAKUR, R. New Millennium, New Perspectives: The United Nations, Security, and Governance. New York: United Nations University Press, 2014. p. 150-159.

STEFANENKO, T. G. Ètnopsihologija [Ethnopsychology]. 4. ed. Moscow: Aspect Press, 2009.

WANG, L. J.; LEHTOMAKI, E. Bilingual education and beyond: how school settings shape the Chinese Yi minority's socio-cultural attachments. International Journal of Bilingual Education and Bilingualism, London, 2021, ahead of print. DOI: https://doi.org/10.1080/13670050.2021.1905602

YUROCHKIN, D. M. Ètnokul'turnaja samoidentifikacija individa v polikul'turnom prostranstve [Ethnocultural self-identification of individuals in a multicultural environment]. Sovremennye Problemy Nauki i Obrazovanija [Modern Problems of Science and Education], Moscow, n. 4, p. 560, 2014. Available: https://scienceeducation.ru/ru/article/view?id=13830. Access: 7 Dec. 2021. 


\section{How to refer to this paper}

BAISHEVA, M. I.; ALEKSEEVA, I. S.; MAKAROVA, T. A.; PERMYAKOVA, A. V.; ILINOVA, T. L. Formation of the ethnocultural autonomy of children with ethno-pedagogical values of arctic peoples. Revista online de Política e Gestão Educacional, Araraquara, v. 25, n. $\quad 3, \quad$ p. 2443-2458, Sep./Dec. 2021. e-ISSN:1519-9029. DOI: https://doi.org/10.22633/rpge.v25i2.15921

Submitted: $27 / 09 / 2021$

Required revisions: $23 / 10 / 2021$

Approved: 25/11/2021

Published: 08/12/2021 